\title{
Faktor-Faktor yang Memengaruhi Praktik Keamanan dalam Penggunaan Insektisida Rumah Tangga di Kecamatan Pangandaran
}

\author{
Factors that Affect the Safety Practices of Using Household Insecticides in Pangandaran \\ Sub-District
}

\begin{abstract}
Nurul Hidayati Kusumastuti1 ${ }^{*}$, Pandji Wibawa Dhewantara ${ }^{2}$, Nova Pramestuti ${ }^{3}$
${ }^{1}$ Dinas Kesehatan Kabupaten Demak, Jl. Sultan Hadiwijaya No 44 Demak 59515, Jawa Tengah, Indonesia. ${ }^{2}$ Loka Litbangkes Pangandaran, Badan Penelitian dan Pengembangan Kesehatan, Kementerian Kesehatan Republik Indonesia, Jl. Raya Pangandaran KM.03 Kp. Kamurang Ds. Babakan, Pangandaran 46396, Jawa Barat, Indonesia.

${ }^{3}$ Balai Litbangkes Banjarnegara, Badan Penelitian dan Pengembangan Kesehatan, Kementerian Kesehatan Republik Indonesia, Jl. Selamanik No 16 A Banjarnegara 53415, Jawa Tengah, Indonesia.
\end{abstract}

\begin{abstract}
The unsafe and improper use of household insecticides represents a major hazard to the environment and human health. Most of people in Pangandaran Sub-District used household insecticides, even more than ten years. The aim of this study was to analyse factors that affect in safety practices of using household insecticide. The research was conducted from April to July 2014 in Pangandaran sub-district. A total of 374 household participated in this study through interviews. Data collected includes characteristics of respondents, educational status, knowledge, attitudes and practices regarding safe insecticide usage. Chisquare test ( $(2)$ was used to measure the possible association between variables and continued with logistic regression. The majority of respondents were lack of safety practices of using household insecticide (60\%). The levels of education $(p=0.00)$ and knowledge $(p=0.03)$ was associated with safe practices in insecticide use. However, according to logistic regression that education level had more influence towards safe insecticide use. Therefore, it is necessary to increase community knowledge through field demonstrations by health workers about the use of household insecticides safely and properly.
\end{abstract}

Keywords: Household Insecticide, Practice, Safety, Pangandaran

\begin{abstract}
Abstrak. Penggunaan insektisida rumah tangga yang tidak aman dan tidak tepat dapat membahayakan lingkungan dan kesehatan manusia. Sebagian besar masyarakat di Kecamatan Pangandaran menggunakan insektisida rumah tangga, bahkan lebih dari sepuluh tahun. Tujuan dari penelitian ini adalah untuk menganalisis faktor-faktor yang memengaruhi praktik menjaga keamanan dalam penggunaan insektisida rumah tangga. Penelitian ini dilakukan dari bulan April hingga Juli 2014 di Kecamatan Pangandaran. Sebanyak 374 rumah tangga berpartisipasi dalam penelitian ini melalui wawancara. Data yang dikumpulkan meliputi karakteristik responden, status pendidikan, pengetahuan, sikap dan praktik mengenai penggunaan insektisida yang aman. Uji Chi-square $(\chi 2)$ digunakan untuk menganalisis hubungan antar variabel dan dilanjutkan dengan regresi logistik. Mayoritas responden mempunyai praktik yang kurang aman dalam menggunakan insektisida rumah tangga (60\%). Tingkat pendidikan $(p=0,00)$ dan pengetahuan $(p=0,03)$ berhubungan dengan praktik menjaga keamanan ketika menggunakan insektisida rumah tangga. Namun, hasil dari regresi logistik menunjukkan tingkat pendidikan lebih berpengaruh terhadap penggunaan insektisida yang aman. Oleh karena itu, perlu untuk meningkatkan pengetahuan masyarakat melalui demonstrasi lapangan oleh petugas kesehatan tentang penggunaan insektisida rumah tangga secara aman dan tepat.
\end{abstract}

Kata Kunci: Insektisida Rumah Tangga, Praktik, Keamanan, Pangandaran 


\section{PENDAHULUAN}

Salah satu upaya untuk memutus rantai penularan DBD adalah dengan pengendalian vektor penyakit tersebut, yaitu nyamuk. Upaya pemerintah dalam pengendalian nyamuk DBD adalah dengan melakukan program 3M (menguras, menutup, mendaur ulang) plus menghindari kontak nyamuk. Salah satu upaya masyarakat dalam menghindari kontak dengan nyamuk adalah dengan penggunaan obat anti nyamuk (insektisida). Penggunaan insektisida dalam pengendalian vektor di masyarakat dapat menguntungkan sekaligus merugikan. Insektisida jika digunakan secara tepat baik dari segi sasaran, dosis, waktu dan cakupan akan mampu mengendalikan vektor dan mengurangi dampak negatif terhadap lingkungan serta organisme yang bukan sasaran. ${ }^{1}$ Akan tetapi, jika penggunaannya dengan dosis dan cara yang tidak tepat serta dalam jangka waktu lama dapat menyebabkan matinya musuh alami dan terjadi resistensi vektor sehingga menurunkan efektivitas insektisida. Akibat resistensi vektor tersebut terhadap insektisida menyebabkan penggunaan insektisida meningkat. $^{2}$

Insektisida terdiri atas beberapa jenis bahan kimia yang berbeda, antara lain organoklorin, organofosfat, karbamat, piretroid dan DEET. Penggunaan organoklorin telah dilarang di dunia dan Indonesia. ${ }^{3}$ Racun insektisida tersebut tidak hanya dirasakan oleh serangga sasaran, tetapi bisa berakibat terhadap hewan peliharaan maupun manusia. ${ }^{1}$ Pada manusia, anak-anak merupakan kelompok yang rentan terkena efek insektisida, karena mereka cenderung memasukkan berbagai jenis barang yang ditemui ke dalam mulutnya. Jika yang dimasukkan adalah insektisida yang merupakan bahan kimia, dapat menimbulkan resiko gangguan kesehatan. ${ }^{4}$ Insektisida meracuni tubuh melalui beberapa cara yaitu tertelan, terhirup, terkena kulit atau mata. ${ }^{1}$

Data hasil Riset Kesehatan Dasar (Riskesdas) di Indonesia tahun 2010 menunjukkan bahwa penggunaan insektisida di Propinsi Jawa Barat secara keseluruhan berada di atas rata-rata nasional. Baik insektisida bakar, mat elektrik, repelan maupun aerosol. ${ }^{5}$ Sedangkan data Riskesdas 2013 menunjukkan penggunakan insektisida bakar dan insektisida lain hampir sama dengan rerata nasional hanya penggunaan repelan yang diatas rata-rata nasional. ${ }^{6}$ Data hasil penelitian penggunaan insektisida telah dilakukan di berbagai wilayah di Indonesia, termasuk di Pangandaran. 7, 8, 9,10,11

Pangandaran merupakan daerah wisata alam dari pantai hingga air terjun. Tempat wisata Pangandaran tidak hanya dikunjungi wisatawan lokal tetapi juga wisatawan mancanegara. Jumlah kunjungan wisatawan mancanegara ke kawasan wisata Pangandaran, Jawa Barat, meningkat seiring dengan musim libur di Eropa yang jatuh pada bulan Juli hingga pertengahan September. Hal ini tentunya berdampak positif bagi Kabupaten Pangandaran, terutama karena dapat meningkatkan pendapatan asli daerah dari sektor pariwisata.

Namun, ada bahaya mengintai dibalik indahnya Pangandaran, karena hasil penelitian menunjukkan adanya keberadaan vektor DBD $^{12,13}$ dan vektor malaria ${ }^{14,} 15$ di Kabupaten Pangandaran. Hasil penelitian Hendri dkk menunjukkan vektor DBD di Pasar Wisata Kabupaten Pangandaran termasuk kategori sedang dengan nilai House Index (HI) sebesar 29,20 \%, Container Index (CI) 9,30\% dan Breteau Index (BI) sebesar 40,6\%.12 Akan tetapi, hasil penelitian Prasetyowati dkk di tahun berikutnya menunjukkan peningkatan $\mathrm{HI}$ dan $\mathrm{CI}$ selain itu pada penelitian tersebut juga ditemukan aktivitas nokturnal vektor DBD. Hal ini memungkinkan vektor DBD tidak hanya menghisap darah di siang hari, tetapi juga di malam hari. ${ }^{13}$

Hasil penelitian Hakim dkk, menunjukkan keberadaan vektor malaria di Kabupaten Pangandaran dengan delapan spesies Anopheles $s p$. yang berhasil diidentifikasi. Spesies tersebut antara lain An. vagus 704 ekor (67,89\%), An. kochi 168 ekor (16,2\%), An. sundaicus 69 ekor (6,65\%), An. barbirostris 63 ekor (6,08\%), An.aconitus 12 ekor $(1,16 \%)$, An. subpictus sembilan ekor $(0,87 \%), A n$. anularis tujuh ekor $(0,67 \%)$, dan An.indefinitus lima ekor $(0,48 \%) .{ }^{13}$ Selain itu hasil penelitian Ridwan dkk, menunjukkan di tujuh kecamatan terdapat tempat perkembangbiakan Anopheles spp dengan enam kecamatan diantaranya berada di daerah tujuan wisata. ${ }^{15}$

Dalam upaya pengendalian DBD, Kusumastuti mengatakan bahwa masyarakat Pangandaran menggunakan beberapa jenis insektisida rumah tangga yang terdiri dari obat nyamuk bakar, elektrik (cair dan keeping padat/mat), semprot, dan oles/repelen. Namun, ketidaktahuan masyarakat mengenai dampak negatif penggunaan insektisida menjadikan insektisida masih merupakan upaya dominan dalam menghindari gangguan nyamuk. ${ }^{16}$ Oleh sebab itu dalam tulisan ini akan lebih dirinci mengenai faktor-faktor yang memengaruhi praktik menjaga keamanan dalam penggunaan insektisida.

Penelitian di Kelurahan Kutowinangun ${ }^{7}$ dan Kecamatan Tingkir Kota Salatiga ${ }^{8}$ mengungkapkan hubungan berbagai faktor terhadap perilaku penggunaan insektisida secara umum, bukan mengenai perilaku yang aman ketika menggunakan insektisida. Penelitian di 
Kabupaten Bogor, Depok, Tangerang Bekasi ${ }^{9}$ serta Provinsi Bali10,11 telah meneliti perilaku yang aman dalam menggunakan insektisida tetapi belum mengungkapkan hubungan secara bivariat dan multivariat dengan faktor yang lain. Tujuan penelitian ini untuk menganalisis faktor-faktor yang memengaruhi praktik menjaga keamanan dalam penggunaan insektisida rumah tangga di Kecamatan Pangandaran.

\section{BAHAN DAN METODE}

Jenis penelitian ini adalah observasional dengan desain potong lintang (cross-sectional). Populasi dalam penelitian ini adalah anggota masyarakat yang menempati rumah/bangunan di Kecamatan Pangandaran pada saat pelaksanaan penelitian sebanyak 3070 rumah. ${ }^{16}$ Perhitungan sampel minimal digunakan rumus perhitungan sampel mutlak dari WHO sebagai berikut. ${ }^{17}$

$\boldsymbol{n}=\frac{Z_{1-\propto / 2}^{2} \boldsymbol{p} \boldsymbol{q}}{\boldsymbol{d}^{2}}$

$$
\begin{aligned}
& \text { Keterangan: } \\
& \mathrm{n}=\text { jumlah sampel minimal yang diperlukan } \\
& \mathrm{p}=\text { proporsi Bruto Indeks Larva } \\
& \\
& \text { Pangandaran } \rightarrow 0,406 .{ }^{15} \\
& \mathrm{q}=(1-\mathrm{p})=\text { proporsi rumah penduduk } \\
& \text { negatif larva } \rightarrow 0,594 \\
& \mathrm{~d}= \text { presisi absolut } \rightarrow \alpha=0,05 \text { maka } \mathrm{Z}^{2} 1-\alpha / 2= \\
& 1.96^{2}
\end{aligned}
$$

Sesuai hasil perhitungan sampel minimal dengan rumus diatas maka didapat jumlah sampel minimal yang diperlukan dalam penelitian adalah 374 rumah tangga. Kriteria inklusi dalam penelitian ini adalah bersedia diwawancara, menggunakan insektisida rumah tangga anti nyamuk, dan anggota rumah tangga (ART) yang berusia $>15$ tahun. Kriteria eksklusi dalam penelitian ini adalah responden yang menderita cacat fisik (tuna rungu, tuna wicara), cacat mental atau responden lanjut usia (lebih dari enam puluh tahun $)^{18}$ yang sudah tidak bisa berkomunikasi dengan baik dan tidak ada ART pengganti lain.

Metode pemilihan sampel dalam laporan menggunakan teknik multi stage-sampling. ${ }^{19}$ Desa di Kecamatan Pangandaran terdiri dari tiga dusun,20 tiap dusun diambil sampel dengan melakukan simple random sampling dari Rukun Warga (RW) setempat. Rukun Warga yang terpilih dilakukan pengelompokan berdasarkan jumlah Rukun Tetangga (RT) dan sampel kembali dengan random sampling untuk menentukan RT terpilih. Banyaknya rumah tangga yang diwawancara di setiap RT ditentukan dengan melakukan proporsi jumlah rumah tangga dari tiap- tiap RT.
Data diperoleh dengan melakukan wawancara terhadap salah satu anggota rumah tangga menggunakan kuesioner semi terbuka yang telah dilakukan uji coba. Pengolahan data dimulai dengan editing untuk diteliti ulang dan diperiksa ketetapan atau kesesuaian jawaban. Kemudian melakukan pengkodean data agar mudah dalam pengolahannya, entry data dan mengelompokkan data menurut sifatnya yang sesuai dengan tujuan penelitian. ${ }^{19}$

Analisis data secara univariat, bivariat, dan multivariat dengan menggunakan program SPSS 16 dengan nomor seri 5061284. Data yang digunakan dalam analisis univariat adalah praktik keamanan ketika menggunakan insektisida yang ditampilkan dalam bentuk diagram lingkaran. Praktik keamanan dalam penggunaan insektisida rumah tangga adalah praktik yang dilakukan masyarakat untuk meminimalisir terjadinya bahaya ketika menggunakan insektisida. Praktik keamanan yang dimaksud meliputi: 1) mengikuti petunjuk yang terdapat dalam bungkus insektisida, 2) mencuci tangan setelah menggunakan insektisida, 3) menggunakan insektisida semprot dengan selang lebih dari satu jam sebelum menggunakan ruangan, 4) tidak menyemprot ketika ada anggota rumah tangga lain, hewan peliharaan dan makanan, 5) memisahkan insektisida yang tidak digunakan dengan bahan makanan, 6) memisahkan sisa insektisida dengan sampah lain, 7) menyimpan insektisida yang tidak digunakan pada tempat yang tidak mudah dijangkau anak-anak. Kategori skor perilaku: baik (skor $>70$ ), sedang (skor 4070), kurang (<40).

Data dalam analisis bivariat dan multivariat adalah karakteristik individu yang meliputi jenis kelamin, umur, pendidikan, pekerjaan jumlah ART dalam keluarga, serta pengetahuan tentang insektisida rumah tangga dan sikap terhadap praktik menjaga keamanan ketika menggunakan insektisida rumah tangga. Kategori skor pengetahuan: baik (skor $>70$ ), kurang (skor 4070), sangat kurang $(<40)$. Kategori skor sikap: baik (skor $>70$ ), sedang (skor 40-70), kurang $(<40)$.

Pada analisis bivariat data diuji menggunakan Chi-square untuk menganalisis hubungan antara masing-masing faktor terhadap praktik keamanan dalam penggunaan insektisida rumah tangga. Pada analisis multivariat data diuji menggunakan regresi logistik untuk menentukan faktor yang berpengaruh terhadap praktik keamanan. ketika menggunakan insektisida rumah tangga. 
Tabel 1. Hasil Analisis Faktor -Faktor yang Memengaruhi Praktik Menjaga Keamanan dalam Penggunaan Insektisida Rumah Tangga di Kecamatan Pangandaran

\begin{tabular}{|c|c|c|c|c|c|c|c|c|c|c|}
\hline \multirow{2}{*}{\multicolumn{2}{|c|}{ Variabel }} & \multicolumn{2}{|c|}{ Praktik Kurang } & \multicolumn{2}{|c|}{ Praktik Sedang } & \multicolumn{2}{|c|}{ Praktik Baik } & \multicolumn{2}{|c|}{ Total } & \multirow{2}{*}{ p-value } \\
\hline & & $n(223)$ & $59,60 \%$ & $\mathrm{n}(145)$ & $38,80 \%$ & $n(6)$ & $1,60 \%$ & $\mathrm{n}(374)$ & $100 \%$ & \\
\hline \multirow{2}{*}{$\begin{array}{l}\text { Jenis } \\
\text { Kelamin }\end{array}$} & Laki-laki & 60 & $16,00 \%$ & 32 & $8,60 \%$ & 4 & $1,10 \%$ & 96 & $25,70 \%$ & \multirow{2}{*}{0,95} \\
\hline & Perempuan & 163 & $43,60 \%$ & 113 & $30,20 \%$ & 2 & $0,50 \%$ & 278 & $74,30 \%$ & \\
\hline \multirow{3}{*}{$\begin{array}{l}\text { Kelompok } \\
\text { Umur }\end{array}$} & $17-31$ & 42 & $11,20 \%$ & 37 & $9,90 \%$ & 1 & $0,30 \%$ & 80 & $21,40 \%$ & \multirow{3}{*}{0,09} \\
\hline & $32-59$ & 137 & $36,60 \%$ & 88 & $23,50 \%$ & 4 & $1,10 \%$ & 229 & $61,20 \%$ & \\
\hline & $59-99$ & 44 & $11,80 \%$ & 20 & $5,30 \%$ & 1 & $0,30 \%$ & 65 & $17,40 \%$ & \\
\hline \multirow{5}{*}{ Jumlah ART } & $1-2$ & 44 & $11,80 \%$ & 27 & $7,20 \%$ & 1 & $0,30 \%$ & 72 & $19,30 \%$ & \multirow{5}{*}{0,56} \\
\hline & $3-4$ & 125 & $33,40 \%$ & 77 & $20,60 \%$ & 2 & $0,50 \%$ & 204 & $54,60 \%$ & \\
\hline & $5-6$ & 43 & $11,50 \%$ & 37 & $9,90 \%$ & 2 & $0,50 \%$ & 82 & $21,90 \%$ & \\
\hline & $7-8$ & 9 & $2,40 \%$ & 4 & $1,10 \%$ & 1 & $0,30 \%$ & 14 & $3,80 \%$ & \\
\hline & $9-10$ & 2 & $0,50 \%$ & 0 & $0,00 \%$ & 0 & $0,00 \%$ & 2 & $0,50 \%$ & \\
\hline \multirow{6}{*}{ Pendidikan } & $\begin{array}{l}\text { Tidak/belum } \\
\text { sekolah }\end{array}$ & 6 & $1,60 \%$ & 2 & $0,50 \%$ & 0 & $0,00 \%$ & 8 & $2,10 \%$ & \multirow{6}{*}{0,00} \\
\hline & $\begin{array}{l}\text { Tidak tamat } \\
\text { dan tamat } \\
\text { SD/MI }\end{array}$ & 129 & $34,49 \%$ & 46 & $12,30 \%$ & 2 & $0,53 \%$ & 177 & $47,33 \%$ & \\
\hline & $\begin{array}{l}\text { Tamat } \\
\text { SLTP/MTS }\end{array}$ & 44 & $11,80 \%$ & 32 & $8,60 \%$ & 0 & $0,00 \%$ & 76 & $20,30 \%$ & \\
\hline & $\begin{array}{l}\text { Tamat } \\
\text { SLTA/MA }\end{array}$ & 35 & $9,40 \%$ & 51 & $13,60 \%$ & 3 & $0,80 \%$ & 89 & $23,80 \%$ & \\
\hline & $\begin{array}{l}\text { Tamat } \\
\text { D1/D2/D3 }\end{array}$ & 2 & $0,50 \%$ & 4 & $1,10 \%$ & 0 & $0,00 \%$ & 6 & $1,60 \%$ & \\
\hline & Tamat PT & 7 & $1,90 \%$ & 10 & $2,70 \%$ & 1 & $0,30 \%$ & 18 & $4,80 \%$ & \\
\hline \multirow{5}{*}{ Pekerjaan } & $\begin{array}{l}\text { PNS/TNI/Polri } \\
\text { /BUMD }\end{array}$ & 8 & $2,10 \%$ & 9 & $2,40 \%$ & 0 & $0,00 \%$ & 17 & $4,50 \%$ & \multirow{5}{*}{0,93} \\
\hline & $\begin{array}{l}\text { Swasta/ } \\
\text { Buruh }\end{array}$ & 23 & $6,15 \%$ & 11 & $2,94 \%$ & 1 & $0,27 \%$ & 35 & $9,36 \%$ & \\
\hline & $\begin{array}{l}\text { Wiraswasta/ } \\
\text { petani/nelayan }\end{array}$ & 92 & $24,60 \%$ & 48 & $12,83 \%$ & 3 & $0,80 \%$ & 143 & $38,24 \%$ & \\
\hline & $\begin{array}{l}\text { Ibu Rumah } \\
\text { Tangga }\end{array}$ & 96 & $25,70 \%$ & 72 & $19,30 \%$ & 2 & $0,50 \%$ & 170 & $45,50 \%$ & \\
\hline & Belum Bekerja & 4 & $1,10 \%$ & 5 & $1,30 \%$ & 0 & $0,00 \%$ & 9 & $2,40 \%$ & \\
\hline \multirow{3}{*}{$\begin{array}{l}\text { Penggunaan } \\
\text { obat nyamuk }\end{array}$} & Ya, setiap hari & 185 & $49,50 \%$ & 110 & $29,40 \%$ & 5 & $1,30 \%$ & 300 & $80,20 \%$ & \multirow{3}{*}{0,16} \\
\hline & $\begin{array}{l}\text { Ya, kadang- } \\
\text { kadang }\end{array}$ & 34 & $9,10 \%$ & 31 & $8,30 \%$ & 1 & $0,30 \%$ & 66 & $17,60 \%$ & \\
\hline & $\begin{array}{l}\text { Tidak, tapi } \\
\text { pernah }\end{array}$ & 4 & $1,10 \%$ & 4 & $1,10 \%$ & 0 & $0,00 \%$ & 8 & $2,10 \%$ & \\
\hline \multirow{2}{*}{$\begin{array}{l}\text { Pengetahuan } \\
\text { mengenai } \\
\text { Insektisida } \\
\text { rumah } \\
\text { tangga }\end{array}$} & $\begin{array}{l}\text { Pengetahuan } \\
\text { sangat kurang }\end{array}$ & 201 & $53,70 \%$ & 119 & $31,80 \%$ & 5 & $1,30 \%$ & 325 & $86,90 \%$ & \multirow[b]{2}{*}{0,03} \\
\hline & $\begin{array}{l}\text { Pengetahuan } \\
\text { kurang }\end{array}$ & 22 & $5,90 \%$ & 26 & $7,00 \%$ & 1 & $0,30 \%$ & 49 & $13,10 \%$ & \\
\hline \multirow{3}{*}{$\begin{array}{l}\text { Sikap } \\
\text { terhadap } \\
\text { Insektisida } \\
\text { rumah } \\
\text { tangga }\end{array}$} & Sikap kurang & 0 & $0,00 \%$ & 1 & $0,30 \%$ & 0 & $0,00 \%$ & 1 & $0,30 \%$ & \multirow{3}{*}{0,21} \\
\hline & Sikap sedang & 116 & $31,00 \%$ & 60 & $16,00 \%$ & 4 & $1,10 \%$ & 180 & $48,10 \%$ & \\
\hline & Sikap baik & 107 & $28,60 \%$ & 84 & $22,50 \%$ & 2 & $0,50 \%$ & 193 & $51,60 \%$ & \\
\hline
\end{tabular}


Tabel 2. Analisis Multivariat Regresi Logistik Praktik Keamanan dalam Penggunaan Insektisida di Kecamatan Pangandaran

\begin{tabular}{llcccc}
\hline & Variabel & S.E. & \multirow{2}{*}{ Sig. } & 95\% C.I.for EXP(B) \\
\cline { 4 - 5 } & Jenis_kelamin & 0,346 & 0,69 & 0,583 & Upper \\
& Kel_umur & 0,237 & 0,624 & 0,705 & 1,789 \\
& Jumlah_ART & 0,097 & 0,288 & 0,745 & 1,091 \\
Analisis & Pendidikan & 0,125 & $\mathbf{0 , 0 0 9}$ & 1,085 & 1,772 \\
Awal & Pekerjaan & 0,076 & 0,071 & 0,988 & 1,331 \\
& Pengguna_obat nyamuk & 0,302 & 0,534 & 0,458 & 1,498 \\
& Pengetahuan_insektisida & 0,384 & 0,055 & 0,984 & 4,435 \\
& Sikap_insektisida & 0,283 & 0,536 & 0,684 & 2,072 \\
& Constant & 1,367 & 0,001 & & 2,239 \\
\hline Analisis & Jumlah_ART & 0,341 & 0,684 & 0,589 & 1,462 \\
Tanpa & Pekerjaan & 0,227 & 0,776 & 0,601 & 1,123 \\
Pentor & Pengguna_obat nyamuk & 0,095 & 0,458 & 0,773 & 1,246 \\
& Kel_Pengetahuan & 0,072 & 0,273 & 0,94 & 1,617 \\
& Kel_Sikap & 0,365 & 0,72 & 0,499 & 5,793
\end{tabular}

\section{HASIL}

Hasil analisis praktik menjaga keamanan dalam penggunaan insektisida rumah tangga ditampilkan dalam Gambar 1. Sebagian besar masyarakat Pangandaran mempunyai praktik yang kurang dalam menjaga keamanan ketika menggunakan insektisida rumah tangga (60\%), dan hanya sedikit saja yang memiliki praktik yang baik.

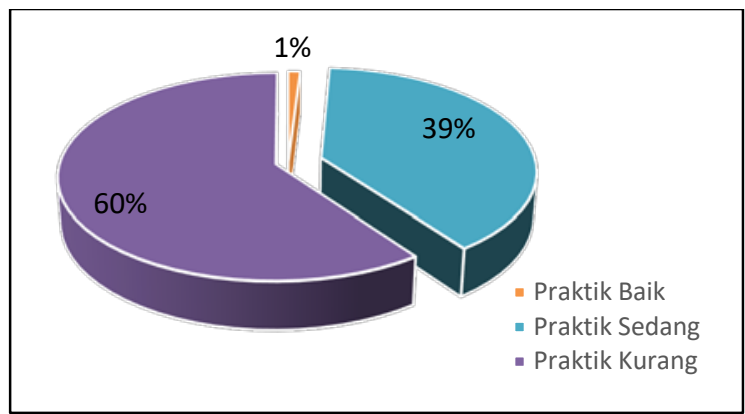

Gambar 1. Praktik menjaga keamanan dalam penggunaan insektisida rumah tangga

Berdasarkan tabel 1 terlihat bahwa variabel yang berhubungan dengan praktik menjaga keamanan ketika menggunakan insektisida rumah tangga adalah pendidikan dan pengetahuan. Masyarakat yang praktiknya kurang dalam menjaga keamanan ketika menggunakan insektida rumah tangga mayoritas dengan tingkat pendidikan SD $(34,49 \%)$ dan memiliki pengetahuan sangat kurang mengenai insektisida rumah tangga $(53,7 \%)$.

Hasil analisis regresi logistik menunjukkan bahwa pendidikan merupakan faktor yang berpengaruh terhadap praktik keamanan ketika menggunakan insektisida rumah tangga di Kecamatan Pangandaran (Tabel 2).

\section{PEMBAHASAN}

Masyarakat Pangandaran memiliki praktik yang kurang dalam menjaga keamanan ketika menggunakan insektisida rumah tangga. Hal ini dapat dianalisis ketika menjawab pertanyaan apakah masyarakat Pangandaran membaca petunjuk pada label yang tertera pada kemasan, yang mayoritas menjawab tidak membaca petunjuk tersebut. Masyarakat juga masih kurang dalam hal menjaga keamanan, terbukti banyaknya jawaban yang mengatakan menggunakan ruangan kurang dari satu jam setelah waktu semprot insektisida dan 
menyemprotkan insektisida ketika ada anggota keluarga lain. Kenyataan dimasyarakat diperberat dengan hanya sebagian kecil masyarakat Pangandaran yang menyimpan insektisida dengan benar, jauh dari jangkauan anak-anak. Masyarakat membuang sisa insektisida bersama sampah lain sehingga ikut tercampur ketika dibawa petugas pengangkut sampah dan mudah ikut terbakar.

Praktik-praktik tersebut tidak sesuai pada petunjuk di Michigan State University Extension tahun 2006 mengenai perilaku aman dalam menggunakan insektisida. Berdasarkan petunjuk di Michigan State University Extension perilaku aman ketika menggunakan insektisida meliputi: 1) menjauhkan insektisida dari anak-anak, makanan, atau tidak disimpan bersama makanan; 2) tidak menyemprot ketika ada orang di ruangan, makanan, hewan peliharaan; 3) tidak menggunakan ruangan setelah tiga puluh menit selesai disemprot; 4) insekstisida tidak disimpan ditempat panas, dekat api atau dibuang di tempat pembakaran sampah. ${ }^{21}$

Praktik yang kurang aman dalam menggunakan insektisida rumah tangga dipengaruhi oleh banyak faktor diantaranya jenis kelamin, kelompok umur, pendidikan, pekerjaan, jumlah ART, penggunaan obat nyamuk, pengetahuan dan sikap dalam menjaga keamanan penggunaan insektisida rumah tangga. Kesemua faktor tersebut merupakan faktor predisposisi yang memengaruhi terbentuknya perilaku. ${ }^{19}$ Hasil analisis faktor yang berhubungan dengan praktik menjaga keamanan ketika menggunakan insektisida rumah tangga adalah faktor pendidikan dan pengetahuan. Pengetahuan yang kurang mengenai penggunaan insektisida rumah tangga yang aman sejalan dengan penelitian Wigati dan Susanti. Hal ini diduga karena belum pernah ada penyuluhan dari petugas kesehatan tentang penggunaan insektisida rumah tangga dengan baik dan aman. ${ }^{22}$ Pemakaian insektisida rumah tangga yang kurang baik berkaitan erat dengan sumber informasi tentang pemakaian insektisida. Penelitian di Bali menunjukkan sumber informasi utama sebagian besar responden berasal dari tenaga non kesehatan. Tidak dapat dipungkiri bahwa banyak tenaga kesehatan yang kurang atau bahkan tidak memberikan penyuluhan tentang penggunaan insektisida rumah tangga yang baik dan tepat untuk pencegahan DBD. Sehingga sumber infomasi pemakaian insektisida paling banyak diperoleh responden dari media massa/iklan. ${ }^{23}$

Berdasarkan hasil uji regresi logistik, pendidikan merupakan faktor yang berpengaruh dalam menjaga keamanan ketika menggunakan insektisida rumah tangga dibandingkan pengetahuan. Pendidikan mempunyai signifikan yang paling kecil dan paling stabil dibanding dengan faktor yang lain. Pendidikan yang rendah dimana sebagian masyarakat tidak sekolah dan tidak tamat SD membuat masyarakat tidak mampu memahami informasi yang tertera pada kemasan insektisida yang digunakan. Masyarakat yang berpendidikan menengah dan tinggi pun sebagian besar tidak membaca informasi pada bungkus insektisida, sehingga tidak mengetahui bagaimana cara yang aman dalam menggunakan insektisida. Hal ini sejalan dengan penelitian Pratamawati bahwa sebagian besar responden $(55,7 \%)$ tidak membaca petunjuk pemakaian obat anti nyamuk sebelum memakainya. ${ }^{23}$

Pendidikan yang rendah akan menyebabkan pengetahuan masyarakat rendah mengenai insektisida rumah tangga. Hal ini sesuai dengan penelitian Soerachman dan Anwar tahun 2010 menunjukkan bahwa masyarakat di Bogor, Depok, Tangerang dan Bekasi memiliki pengetahuan yang kurang mengenai pedoman tentang pestisida di tumah tangga. ${ }^{9}$ Akibatnya masyarakat tidak memperhatikan keamanan ketika menggunakan insektisida. Masyarakat hanya menggunakan insektisida untuk menghindari gangguan dari nyamuk tanpa memperhatikan efek buruk yang ditimbulkan dari penggunaan insektisida. ${ }^{16}$ Padahal penggunaan insektisida yang tidak tepat memberikan pengaruh yang buruk baik terhadap manusia, hewan peliharaan dan lingkungan. ${ }^{1}$ Masyarakat juga tidak memperhatikan dimana seharusnya insektisida diletakkan ketika digunakan ataupun disimpan ketika tidak digunakan sehingga aman dari jangkauan anak-anak. Bayi usia 6-12 bulan memiliki risiko yang lebih besar dibanding dengan orang dewasa karena kecenderungan bayi tersebut memasukkan barang apa saja yang ditemui ke dalam mulutnya (fase oral). ${ }^{24}$ Jika yang dimasukkan adalah insektisida bisa membahayakan. Oleh sebab itu, praktik menjaga keamanan ketika menggunakan insektisida harus diperhatikan sehingga akibat buruk dari insektisida bisa ditekan serendah mungkin. Martono dan kawan - kawan juga menyampaikan pemakaian pestisida kimia di tingkat rumah tangga masih berisiko terhadap kesehatan dan lingkungan karena praktik masyarakat masih kurang aman dalam menggunakan insektisida. ${ }^{11}$

Oleh karena itu, pengetahuan masyarakat perlu diperkuat melalui penyuluhan oleh tenaga kesehatan (puskesmas) dan demonstrasi lapangan tentang penggunaan insektisida rumah tangga serta memberikan informasi pada masyarakat untuk selalu membaca aturan penggunaan dan peringatan bahaya penggunaan insektisida tersebut yang ada pada kemasannya. Hal ini sangat penting tetapi justru sering 
dilupakan. Kegiatan peningkatan kapasitas seperti itu akan memberi kesempatan pada masyarakat untuk belajar dan memahami cara menggunakan insektisida dengan aman dan tepat sehingga dapat memberikan kontribusi positif dalam pencegahan DBD. Aman adalah aman untuk diri sendiri dan lingkungan sekitar, sedangkan tepat dalam arti tepat jenis insektisida, tepat cara aplikasi, tepat sasaran, tepat waktu, dan tepat takaran. ${ }^{25}$

Dengan adanya peningkatan pengetahuan diharapkan merubah praktik masyarakat dalam menjaga keamanan ketika menggunakan insektisida rumah tangga. Hal ini didukung oleh penelitian Andiarsa di Kota Makassar menunjukkan bahwa responden yang memiliki pendidikan tinggi memberikan kontribusi yang lebih baik dan bijak dalam penggunaan insektisida, ${ }^{26}$ juga penelitian Prasetyowati bahwa perlu upaya peningkatan pengetahuan, sikap dan perilaku pada penggunaan insektisida rumah tangga pada masyarakat Jakarta Timur. ${ }^{27}$

\section{KESIMPULAN}

Praktik masyarakat Pangandaran dalam menjaga keamanan ketika menggunakan insektisida rumah tangga masih kurang baik. Faktor utama yang memengaruhi praktik keamanan ketika menggunakan insektisida rumah tangga adalah pendidikan. Oleh karena itu, diperlukan peningkatan pengetahuan masyarakat melalui penyuluhan oleh tenaga kesehatan (puskesmas) dan demonstrasi lapangan tentang penggunaan insektisida rumah tangga secara aman dan tepat.

\section{UCAPAN TERIMA KASIH}

Penulis mengucapkan terima kasih kepada Badan Litbang Kesehatan atas pemberian kesempatan penelitian Riset Binaan Kesehatan tahun 2014. Kepala Desa Pangandaran dan Desa Pananjung serta seluruh masyarakat Pangandaran atas informasi yang telah diberikan dalam penelitian. Kepala Dinas Kesehatan Kabupaten Pangandaran, Kepala Puskesmas Pangandaran beserta staff yang telah membantu dalam pelaksanaan penelitian. Alm. Prof Supratman Sukowati, Prof Amrul Munif, Prof Bastaman Basuki dan Dra. Blondine Christina M.Kes atas bimbingan yang telah diberikan serta semua pihak yang tidak bisa disebutkan satu persatu yang telah membantu dalam penyelesaian penelitian.

\section{KONTRIBUSI PENULIS}

Peran penulis pada artikel ini yaitu Nurul Hidayati Kusumastuti sebagai kontributor utama. Pandji Wibawa Dhewantara dan Nova Pramestuti sebagai kontributor anggota. Kontribusi penulis dapat dilihat pada rincian berikut:

\begin{tabular}{lll} 
Conceptualization & $:$ & NHK \\
Data Curation & $:$ & PWD \\
Formal Analysis & $:$ & Semua penulis \\
Investigation & $:$ & NHK, PWD \\
Methodology & $:$ & NHK, PWD \\
Supervision & $:$ & NHK \\
Visualization & $:$ & PWD \\
$\begin{array}{l}\text { Writing-Original } \\
\text { Draft Preparation }\end{array}$ & $:$ & Semua penulis \\
\hline
\end{tabular}

Writing-Review \& : Semua penulis Editing

\section{DAFTAR PUSTAKA}

1. Sukowati S. Masalah Vektor Demam Berdarah Dengue dan Pengendaliannya di Indonesia. Bul Jendela Epidemiol. 2010;2:26-30.

2. Ipa M, Hakim L, Prasetyowati H, Pujiastuti E, Ruliansyah A, Fuadzy $\mathrm{H}$, et al. Pemetaan Status Kerentanan Aedes aegypti Terhadap Insektisida di Indonesia 2015 laporan Akhir Penelitian. Pangandaran; 2015.

3. Raini M. Toksikologi Insektisida Rumah Tangga dan Pencegahan Keracunan. Media Penelit dan Pengemb Kesehat. 2009; XIX(II):27-33.

4. Sujatno A. Antinyamuk Pestisida Dibalik Selimut [Internet]. Jakarta; 2011 May; Available from: https://ylki.or.id/2011 /05/antinyamuk-pestisida-dibalik-selimut/

5. Badan Penelitian dan Pengembangan Kesehatan. Riset Kesehatan Dasar 2010. Jakarta: Kementerian Kesehatan RI; 2011.

6. Badan Penelitian dan Pengembangan Kesehatan. Riset Kesehatan Dasar 2013. Jakarta: Kementerian Kesehatan RI; 2014.

7. Wigati RA, Susanti L. Hubungan karakteristik, pengetahuan, dan sikap dengan perilaku masyarakat dalam 
penggunaan anti nyamuk di Kelurahan Kutowinangun. Bul Penelit Kesehat. 2012;40(3):130-41.

8. Susanti L. Residu Insektisida Rumah tangga aerosol (bahan aktif: kelompok pyrethroid) terhadap nyamuk Culex quinquefasciatus Di Lingkungan Pemukiman Kecamatan Tingkir Kota Salatiga. (Thesis). [Yogyakarta]; 2011.

9. Soerachman R, Anwar A. Pengetahuna dan perilaku masyarakat tentang pestisida di rumah tangga di Bogor, Depok, Tangerang dan Bekasi. Bul Jendela Epidemiol. 2014;42(3):203-12.

10. Pratamawati DA, Irawan AS, Widiarti. Hubungan antara pengetahuan tentang vektor dengan perilaku penggunaan insektisida rumah tangga pada daerah endemis demam berdarah dengue di Provinsi Bali. Vektora. 2012;IV(2):99-116.

11. Martono $\mathrm{H}, \mathrm{Tim}$. Pestisida kimia di tingkat rumah tangga di Kabupaten Badung dan Ubud Propinsi Bali. Jakarta; 2010.

12. Hendri J, Res RN, Prasetyowati H. Tempat perkembangbiakan nyamuk Aedes spp di Pasar Wisata Pangandaran. ASPIRATOR - J Vector-borne Dis Stud. 2010;2(1):23-31.

13. Prasetyowati H, Marina R, Hodijah DN, Widawati M, Wahono T. Survey jentik dan aktifitas nokturnal Aedes Spp. di Pasar Wisata Pangandaran. J Ekol Kesehat. 2015;13(1 Mar):33-42.

14. Hakim L, Wahono $\mathrm{T}$, Ruliansyah A, Kusnandar AJ. Potensi kemunculan kembali malaria di Kabupaten Pangandaran. ASPIRATOR - J Vector-borne Dis Stud. 2018;10(1):37-48.

15. Ridwan W, Ruliansyah A, Kusnandar AJ, Pradani FY. Pemetaan tempat perkembangbiakan potensial Anopheles sp. di tempat wisata Pangandaran. ASPIRATOR J Vector-borne Dis Stud. 2019;11(2):81-90.

16. Kusumastuti NH. Penggunaan insektisida rumah tangga antinyamuk. Widyariset. 2014;17(3):417-24.

17. Ariawan I. Besar dan metode sampel pada penelitian kesehatan. In Jakarta: Pusat
Penelitian Kesehatan Universitas Indonesia; 2012.

18. Pusat Data dan Informasi Kementerian Kesehatan RI. Gambaran kesehatan lanjut usia di Indonesia. Bul Jendela Data dan Inf Kesehat. 2013;1(1):1-18.

19. Notoatmojo S. Metodologi penelitian kesehatan. Jakarta: PT. Rieneka Cipta; 2005.

20. Pemerintah Desa Pangandaran. Profil Desa Pangandaran Kabupaten Ciamis Provinsi Jawa Barat. Pangandaran; 2014.

21. Michigan State University Extension. Selection and use of household insecticides, if needed. Minchigan: Michigan State University Extension; 2006. Available from: http://www.msue.msu.edu/objects/ content_revision/download.cfm/revision_id. 496095/workspace_id.-4/01500539.html/

22. Wigati RA, Susanti L. Hubungan karakteristik, pengetahuan, dan sikap, dengan perilaku masyarakat dalam penggunaan anti nyamuk di Kelurahan Kutowinangun. Bull Heal Res. 2013;40(3):129-38.

23. Pratamawati DA, Irawan AS, Widiarti W. Hubungan antara perilaku penggunaan insektisida rumah tangga dengan riwayat pernah sakit demam berdarah di Provinsi Bali Tahun 2011. Spirakel. 2017;7(2):15-27.

24. Meihartati T, Widia L, Chandra S. Hubungan antara kebersihan fase oral pada bayi usia 612 bulan dengan kejadian diare. J Darul Azhar. 2017;3(1):57-63.

25. Direktorat Pupuk dan Pestisida. Pedoman pembinaan penggunaan pestisida. Jakarta: Kementerian Pertanian; 2011.

26. Andiarsa D, Sembiring WSRG. Perilaku penggunaan insektisida pada rumah tangga di tiga kabupaten/kota Provinsi Sulawesi Selatan. J Buski. 2015;5(3):149-54.

27. Prasetyowati H, Astuti PE, Ruliansyah A Penggunaan insektisida rumah tangga dalam pengendalian populasi Aedes aegypti di daerah endemis demam berdarah dengue (DBD) di Jakarta Timur. Aspirator. 2016;8(1):29-36. 